(E-mail: mv.brailo@gmail.com)

\title{
Modified epoxy matrix with improved properties for protection of transport vehicles
}

\begin{abstract}
It is substantiated that for improving the performance characteristics of vehicle parts, including their corrosion and wear resistance, it is advisable to use protective polymeric composite coatings. It is shown that in order to increase the indexes of physical and mechanical and thermophysical properties in the epoxy binder, it is necessary to introduce additives: modifiers, plasticizers, dispersed and fiber fillers. The introduction of modifiers into the epoxy binder is relevant, and effectively use them in the complex. The influence of modifier and hardener on the adhesion strength and destructive stresses during bending of the developed epoxy composite has been analyzed. The critical content of the components: the MBMA modifier is $0.25 \ldots 0.50$ pts.wt., hardener PEPA $-8 \ldots 10$ wt. per 100 pts.wt. of epoxy oligomer ED-20 was found by the method of mathematical planning of the experiment. The introduction of such ingredients into the epoxy binder increases the adhesion strength of matrix to $\sigma_{a}=28.9 \ldots 31.3 \mathrm{MPa}$ and the fracture stresses during the flexion to $\sigma_{f l}=51.2 \ldots 54.4 \mathrm{MPa}$. The obtained results allow to create materials with improved physical and mechanical properties in the complex.
\end{abstract}

Keywords: composite, epoxy matrix, method of mathematical planning of the experiment, regression equation.

\section{Introduction}

The authors [1-6] have shown the expediency of using composite coatings on a polymeric basis to improve the performance of parts of transport. In this case, not only the choice of a polymer matrix, but also its modification by catalysts, plasticizers and other kinds of additives is of great importance. In this regard, the choice of the widely distributed epoxy resin ED-20 as a basis for the polymer binder is relevant. Coating on the basis of such epoxy oligomer is characterized by increased adhesion, physico-mechanical and thermophysical properties. This leads to an increase in the lifetime of the protective coatings of parts of transport equipment.

In the works [7-12] shown, that in order to improve the properties of coatings in the complex, which operate under conditions of aggressive media and temperature changes, it is advisable to introduce modifiers at the critical content. In this case, it is necessary to introduce active modifiers in the polymer, but also the hardener at the optimal content. This approach allows you to get a material with a homogeneous structure. It ensures maximum increase in the indexes of characteristics.

In this context, in order to reduce the number of experimental studies, it is proposed to conduct mathematical planning of the experiment. On the previous stage, the influence of the number of ingredients on the basic properties of epoxy CM was investigated. The critical content of the 2,4-diaminoazobenzene - 4'-carboxylic acid (MBMA) modifier, and a polyethylene polyamine hardener (PEPA) in the polymer matrix was established. However, from a practical standpoint, it is important to form composites with these components at different content in the epoxy resin. In this context, it is expedient and necessary to use the method of mathematical planning of the experiment. It allows to reduce the number of conducted studies and optimize the contents of the ingredients to obtain a matrix with the maximal values of the selected characteristics. Aim of work is to optimize the content of modifier and hardener for the protective coatings of the transport equipment by the method of mathematical planning of the experiment.

\section{Results and discussion}

The adhesive strength at normal break and fracture stresses during the flexion of epoxy composites at the different content of modifier and hardener (2,4-diaminoazobenzene - 4'-carboxylic acid and polyethylene polyamine respectively) was investigated. For standardization, as well as for simplification of calculations, each component (filler) is encoded by conditional units taking into account variations (Table 1). 
Levels of variables on conditional and natural scale

\begin{tabular}{|c|c|c|c|c|c|c|}
\hline \multirow{2}{*}{ Components } & \multirow{2}{*}{ Factor } & \multirow{2}{*}{$\begin{array}{c}\text { Average level, } \\
q, \text { pts. wt. }\end{array}$} & $\begin{array}{c}\text { Variation step, } \\
\Delta q, \text { pts. wt. }\end{array}$ & \multicolumn{3}{|c|}{$\begin{array}{c}\text { Values of variables (pts. wt.), } \\
\text { corresponding to conditional units }\end{array}$} \\
\cline { 5 - 7 } & & & & -1 & 0 & +1 \\
\hline Modifier MBMA & $x_{1}$ & 0.50 & 0.25 & 0.25 & 0.50 & 0.75 \\
\hline Hardener PEPA & $x_{2}$ & 10 & 2 & 8 & 10 & 12 \\
\hline
\end{tabular}

According to the experiment planning scheme 9 experiments $(N=9)$ were conducted, each of which was repeated three times $(p=3)$ in order to exclude system errors (Table 2$)$. In order that planning matrix to be orthogonal [13-15], the corrected values of $x^{\prime}$ level were entered, which were calculated by the formula:

$$
x_{i}^{\prime}=\left(x_{i}\right)^{2}-\frac{\sum_{u-1}^{N} x_{i u}^{2}}{N} .
$$

The expanded matrix of planning of complete factor experiment (CFE) and its results are shown in Table 3.

Table 2

Scheme of experiment planning

\begin{tabular}{|c|c|c|c|c|c|c|}
\hline № of experiment $(u)$ & $x_{0}$ & $x_{1}$ & $x_{2}$ & $x_{3}=x_{1}^{2}-d$ & $x_{4}=x_{2}^{2}-d$ & $x_{1} x_{2}$ \\
\hline 1 & 1 & -1 & -1 & 0.33 & 0.33 & +1 \\
\hline 2 & 1 & +1 & -1 & 0.33 & 0.33 & -1 \\
\hline 3 & 1 & -1 & +1 & 0.33 & 0.33 & -1 \\
\hline 4 & 1 & +1 & +1 & 0.33 & 0.33 & +1 \\
\hline 5 & 1 & 0 & 0 & -0.67 & -0.67 & 0 \\
\hline 6 & 1 & +1 & 0 & 0.33 & -0.67 & 0 \\
\hline 7 & 1 & -1 & 0 & 0.33 & -0.67 & 0 \\
\hline 8 & 1 & 0 & +1 & -0.67 & 0.33 & 0 \\
\hline 9 & 1 & 0 & -1 & -0.67 & 0.33 & 0 \\
\hline$\sum_{\mathrm{u}-1}^{\mathrm{N}} x_{i u}^{2}$ & 9 & 6 & 6 & 2 & 2 & 4 \\
\hline
\end{tabular}

Table 3

Results of study of adhesive strength at break and fracture stresses during the flexion of the epoxy matrix

\begin{tabular}{|c|c|c|c|c|}
\hline \multirow{2}{*}{$\begin{array}{c}\text { oo } \\
\text { of experiment }\end{array}$} & $\begin{array}{c}\text { Content of components, } \\
\text { q, pts. wt. }\end{array}$ & $\begin{array}{c}\text { Adhesive strength } \\
\text { at break, } \sigma_{a}, \mathrm{MPa}\end{array}$ & $\begin{array}{c}\text { Fracture stresses during } \\
\text { the flexion, } \sigma_{f l}, \mathrm{MPa}\end{array}$ \\
\cline { 2 - 5 } & $x_{1}$ & $x_{2}$ & $y_{1}$ & $y_{2}$ \\
\hline 1 & 0.25 & 8 & 28.2 & 48.4 \\
\hline 2 & 0.75 & 8 & 26.6 & 50.0 \\
\hline 3 & 0.25 & 12 & 27.8 & 51.0 \\
\hline 4 & 0.75 & 12 & 26.4 & 49.3 \\
\hline 5 & 0.50 & 10 & 28.9 & 48.8 \\
\hline 6 & 0.75 & 10 & 27.9 & 50.2 \\
\hline 7 & 0.25 & 10 & 31.3 & 48.2 \\
\hline 8 & 0.50 & 12 & 27.2 & 54.4 \\
\hline 9 & 0.50 & 8 & 25.5 & \\
\hline
\end{tabular}

The mathematical model $y=f\left(x_{1}, x_{2}\right)$ was formed as a regression equation:

$$
y=b_{0}+b_{1} x_{1}+b_{2} x_{2}+b_{11} x_{1}^{2}+b_{22} x_{2}^{2}+b_{12} x_{1} x_{2} .
$$


The regression coefficients were determined by the formula:

$$
b_{i}=\frac{\sum_{u=1}^{N} x_{i} y_{i}}{\sum_{u-1}^{N} x_{i u}^{2}} .
$$

Received coefficients of regression equation are given in Table 4.

Table 4

The coefficients of regression equation

\begin{tabular}{|c|c|c|c|c|c|}
\hline$b_{0}$ & $b_{1}$ & $b_{2}$ & $b_{11}$ & $b_{22}$ & $b_{12}$ \\
\hline 28.81 & -1.07 & 0.18 & 0.83 & -2.42 & 0.05 \\
\hline
\end{tabular}

As a result, in the analysis of the adhesive strength at break, the following regression equation was determined:

$$
y=28.81-1.07 x_{1}+0.18 x_{2}+0.83 x_{1}^{2}-2.42 x_{2}^{2}+0.05 x_{1} x_{2}
$$

For the statistical processing of experiment results, a test of reproducibility of experiments by the Cochran test was conducted:

$$
G=\frac{S_{u \max }^{2}}{\sum_{u=1}^{N} S_{u}^{2}} \leq G_{\left(0,05 ; f_{1} ; f_{2}\right)},
$$

where: $S_{u i}^{2}$ - dispersion of experiment results on combinations of few factor levels for $m=3$; $m-$ number of parallel experiments; $S_{u m a x}^{2}$ - the highest dispersion in design line;

Dispersions of adequacy were determined by the formula:

$$
S_{u i}^{2}=\frac{\sum_{i=1}^{m}\left(y_{i}-\overline{y_{i}}\right)^{2}}{m-1},
$$

where: $y_{i m}$ - value, received from each parallel experiment; $\overline{y_{i}}$ - average value $y$, received in parallel experiments.

Mean square error was determined by formula:

$$
\sigma^{2}\{y\}=\frac{\sum_{i=1}^{N=9} \sigma^{2}\{y\}_{i}}{N(m-1)}
$$

where $\sigma^{2}\{y\}_{i}=\sum_{i=1}^{m=3}\left(y_{i}-\overline{y_{i}}\right)^{2}$

$$
\sigma^{2}\left\{y_{a v}\right\}=\frac{a^{2}\{y\}}{N}, \text { or } S_{b_{0}}^{2}=\frac{S_{0}^{2}}{N}
$$

Dispersion values are shown in Table 5.

Values of dispersions of adequacy $\left(S_{u i}^{2}\right)$ and mean square error $\left(\sigma^{2}\{y\}_{i}\right)$

\begin{tabular}{|c|c|c|c|c|}
\hline \multirow{2}{*}{ № } & The dispersions of adequacy & \multicolumn{2}{|c|}{ The mean square error } \\
\cline { 2 - 5 } & conditional designation & value & conditional designation & value \\
\hline 1 & $S_{u 1}^{2}$ & 0.04 & $\sigma^{2}\{y\}_{1}$ & 0.08 \\
\hline 2 & $S_{u 2}^{2}$ & 0.07 & $\sigma^{2}\{y\}_{2}$ & 0.14 \\
\hline 3 & $S_{u 3}^{2}$ & 0.09 & $\sigma^{2}\{y\}_{3}$ & 0.18 \\
\hline 4 & $S_{u 4}^{2}$ & 0.09 & $\sigma^{2}\{y\}_{4}$ & 0.18 \\
\hline 5 & $S_{u 5}^{2}$ & 0.19 & $\sigma^{2}\{y\}_{5}$ & 0.38 \\
\hline 6 & $S_{u 6}^{2}$ & 0.01 & $\sigma^{2}\{y\}_{6}$ & 0.02 \\
\hline 7 & $S_{u 7}^{2}$ & 0.09 & $\sigma^{2}\{y\}_{7}$ & 0.18 \\
\hline 8 & $S_{u 8}^{2}$ & 0.07 & $\sigma^{2}\{y\}_{8}$ & 0.14 \\
\hline 9 & $S_{u 9}^{2}$ & 0.04 & $\sigma^{2}\{y\}_{9}$ & 0.08 \\
\hline
\end{tabular}




\section{Moreover:}

$$
\begin{aligned}
& \sum_{i=1}^{N} S_{u i}^{2}=0.69 \\
& \sigma^{2}\{y\}=S_{0}^{2}=0.077 .
\end{aligned}
$$

Then the calculated value of the Cochran test at the $5 \%$ level of significance:

$$
G_{\text {calc }}=\frac{S_{u_{\max }}^{2}}{\sum_{i=1}^{N} S_{u i}^{2}} ;
$$

$G_{\text {calc }}=\frac{0.19}{0.69}=0.275$.

Testing the experiment results by the Cochran test [16] for a fixed probability $\alpha=0.05$ confirmed the reproducibility of the experiments. Dispersion of experiment results on combinations of few factor levels: $S_{u \max }^{2}=0.19$. Calculated value of Cochran test: $G_{c a l c}=0.275$.

Table value of Cochran test: $G_{t a b}=0.478$.

That is, the condition (7) is fulfilled:

$$
G_{\text {calc }}=0.275 \leq G_{t a b}=0.478 .
$$

Subsequently, the coefficients significance of regression equation was determined by analyzing the results according to the experimental design (Table 6).

Table 6

The experimental results of study of adhesive strength at break of materials

\begin{tabular}{|c|c|c|c|c|}
\hline \multirow{2}{*}{$№$ of experiment } & \multicolumn{3}{|c|}{ Adhesive strength at break, $\sigma_{a}, \mathrm{MPa}$} & \multirow{2}{*}{ Average value, $\sigma_{a}, \mathrm{MPa}$} \\
\cline { 2 - 4 } & 1 & 2 & 3 & 28.2 \\
\hline 1 & 28.0 & 28.4 & 28.2 & 26.6 \\
\hline 2 & 26.5 & 26.9 & 26.4 & 27.8 \\
\hline 3 & 27.8 & 28.1 & 27.5 & 26.4 \\
\hline 4 & 26.4 & 26.1 & 26.7 & 28.9 \\
\hline 5 & 28.7 & 29.4 & 28.6 & 27.9 \\
\hline 6 & 27.9 & 27.8 & 28.0 & 31.3 \\
\hline 7 & 31.3 & 31.0 & 31.6 & 27.2 \\
\hline 8 & 27.5 & 27.1 & 27.0 & 25.5 \\
\hline 9 & 25.3 & 25.5 & 25.7 & \\
\hline
\end{tabular}

Then the dispersions of regression coefficients (Table 7) were determined by the formula:

$$
S_{b_{i}}^{2}=\frac{S_{0}^{2}}{\sum_{u-1}^{N} x_{i u}^{2}} .
$$

The significance of the regression coefficients was determined by the Student's test [17, 18]. Here with the table $\left(t_{m}\right)$ and calculated criterion $\left(t_{c a l c}\right)$ of Student's test (Table 7) were determined.

Depending on freeness: $f=N(n-1)=9(3-1)=18$ the Student's test value was calculated, which is $t_{T}=2.1$.

Calculated values of Student's test $\left(t_{\text {calc }}\right)$ and coefficients significance were determined: $t_{0}, t_{1}, t_{2}, t_{11}, t_{22}, t_{12}>t$.

Moreover:

$$
t_{i}=\frac{\left|b_{i}\right|}{S_{b_{i}}} .
$$


Dispersion of coefficients of regression $\left(S_{b}^{2}\right)$ and calculated values of Student's criterion $\left(t_{\text {calc }}\right)$

\begin{tabular}{|c|c|c|c|c|}
\hline \multirow{2}{*}{$№$} & \multicolumn{2}{|c|}{ Dispersion of coefficients of regression } & \multicolumn{2}{c|}{ Calculated values of Student's criterion } \\
\cline { 2 - 5 } & conditional designation & value & conditional designation & value \\
\hline 1 & $S_{b_{0}}^{2}$ & 0.009 & $t_{0 p}$ & 301.09 \\
\hline 2 & $S_{b_{1}}^{2}$ & 0.013 & $t_{1 p}$ & 9.44 \\
\hline 3 & $S_{b_{2}}^{2}$ & 0.013 & $t_{2 p}$ & 1.62 \\
\hline 4 & $S_{b_{11}}^{2}$ & 0.038 & $t_{11 p}$ & 4.26 \\
\hline 5 & $S_{b_{22}}^{2}$ & 0.038 & $t_{22 p}$ & 12.34 \\
\hline 6 & $S_{b_{12}}^{2}$ & 0.019 & $t_{12 p}$ & 0.4 \\
\hline
\end{tabular}

Calculated values of Student's criterion $t_{0}, t_{t 1}, t_{11}, t_{22}$ are larger than $t_{T}$, so it was considered that $b_{0}, b_{1}$, $b_{11}, b_{22}$ coefficients of the regression equation are significant. Calculated values $t_{2}, t_{12}$ are lower than $t_{T}$, so it was considered that $b_{2}, b_{12}$ coefficients of the regression equation are insignificant. As a result of rejection of insignificant coefficients, the following regression equation was received:

$$
y=28.81-1.07 x_{1}+0.83 x_{1}^{2}-2.42 x_{2}^{2} .
$$

The adequacy of the model was checked by Fisher test [11]:

$$
F_{c}=\frac{S_{u \max }^{2}}{S_{y}^{2}} \leq F_{\left(0.05 ; f_{a d} ; f_{y}\right)}
$$

where $S_{u \max }^{2}=0.19-$ calculated value of dispersion of adequacy (Table 5);

$$
S_{y}^{2}=\frac{\sum_{i=1}^{N} S_{u i}^{2}}{N}
$$

$S_{y}^{2}=0.077-$ mean square error;

So: $F_{c}=2.49$.

$F_{\left(0.05 ; f_{a d} ; f_{u}\right)}-$ table value of Fisher test in $5 \%$ significance level $\left(f_{1}=N-(k+1)=9-(4+1)=4\right.$, $\left.f_{2}=N(n-1)=9(3-1)=18\right)$. So: $F_{t}=2.93[19]$.

Calculated value of Fisher test is less than table one, so the requirement (10) is fulfilled. It is possible to assume that equation adequately characterizes the composition.

Interpretation process of received mathematical model, as a rule, is not just determination of factors influence. A simple comparison of absolute value of linear coefficients does not determine the relative degree factors influence, since there are also quadratic squared terms and paired interactions. In a detailed analysis of the received adequate model, it is necessary to take into account the fact that for a quadratic model the degree of factor influence on the change of output value is not constant.

Dependencies that connect normalized and natural values of the variables are as follows:

$$
x_{i}=\frac{q_{i}-q_{i 0}}{\Delta q_{i}},
$$

where: $q_{i}$ - value of $i$ experiment factor, $q_{i 0}$ - value of zero level, $\Delta q_{i}$ - variation interval.

Substituting these values in accordance with the formula (13) into the regression equation and transforming it, we receive the following regression equation with the natural values of the variables:

$$
\sigma_{a}=-26.23+13.28 q_{1}^{2}-0.605 q_{2}^{2}-17.56 q_{1}+12.1 q_{2} .
$$

Given equation in natural values allows only predicting the output value for any point in the middle of range of factor variations. However, with its help it is possible to construct graphs of dependence of output value (adhesive strength at break) from any factor (or two factors). Geometric interpretation of the response surface is shown on Fig. 1-3. 


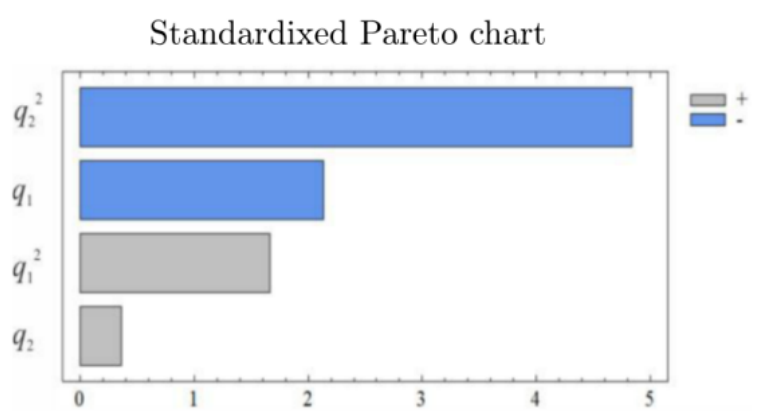

a)

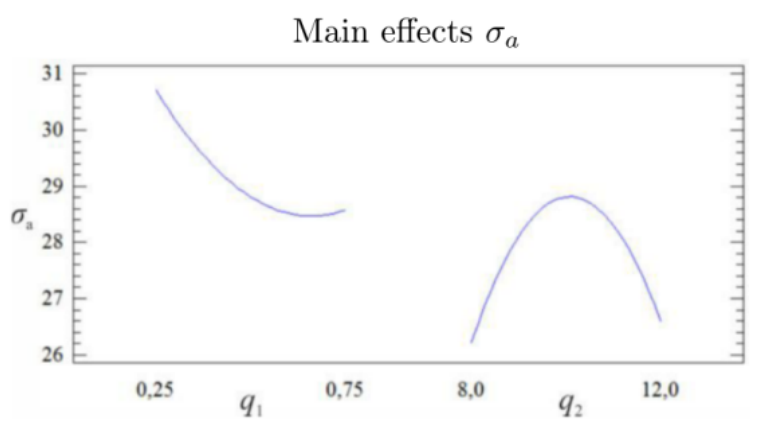

b)

Figure 1. Standardized Pareto chart (a) and main effects (b)

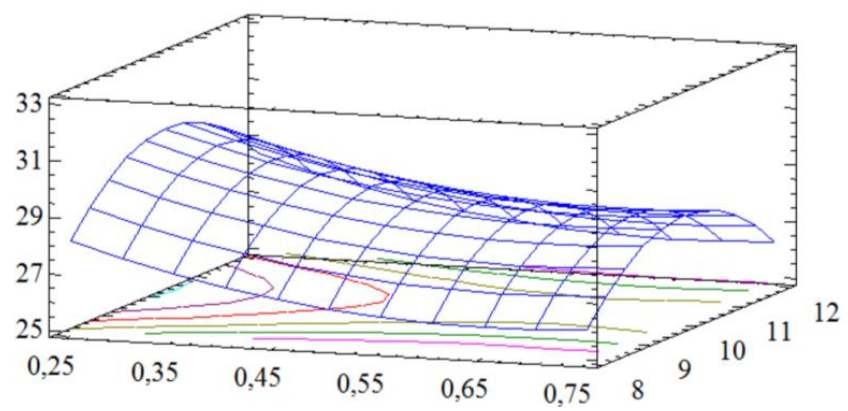

Figure 2. Estimated surface $\sigma_{a}=f\left(q_{1}, q_{2}\right)$

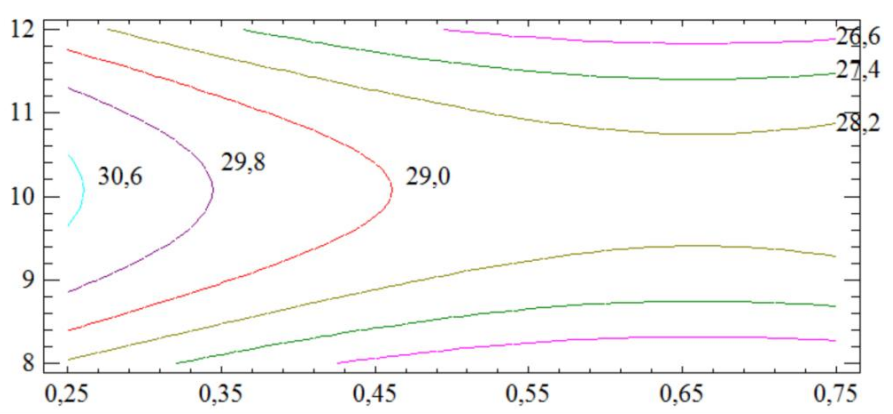

Figure 3. Contours of estimated response surface

On the basis of experimental studies, it has been found that both factors are significant. It should be noted that the effect of the content of the MBMA modifier on the indexes of adhesion strength at break is higher compared to the PEPA hardener (according to the Pareto chart). It was determined that optimal indexes of adhesion strength at break have a developed epoxy composite with a modifier and a hardener at the following contents: the MBMA modifier is $0.25 \ldots 0.50$ parts by mass, PEPA hardener -10 parts by mass, $\left(\sigma_{a}=28.9 \ldots 31.3 \mathrm{MPa}\right)$ by analyzing the calculated response surface. Similarly, to the above calculations scheme, the composition formula was optimized according to the fracture stresses during the flexion indexes. The encoding of natural components values and the experimental design scheme are chosen according to Table 1 and Table 2.

In the process of study results analysis of composites fracture stresses during the flexion, the following values of the regression coefficients were received (Table 8). 
The coefficients of regression equation of fracture stresses during the flexion

\begin{tabular}{|c|c|c|c|c|c|}
\hline$b_{0}$ & $b_{1}$ & $b_{2}$ & $b_{11}$ & $b_{22}$ & $b_{12}$ \\
\hline 50.46 & -0.18 & -0.65 & -0.58 & 0.22 & -0.83 \\
\hline
\end{tabular}

As a result, the following regression equation was found:

$$
y=50.46-0.18 x_{1}-0.65 x_{2}-0.58 x_{1}^{2}-0.22 x_{2}^{2}+0.83 x_{1} x_{2} .
$$

For statistical processing of experiment results, a test of experiments reproducibility was conducted according to the Cochran test [20].

Dispersions values that were calculated by formula (5-7) are shown in Table 9.

Table 9

Values of dispersions of adequacy $\left(S_{u i}^{2}\right)$ and mean square error $\left(\sigma^{2}\{y\}_{i}\right)$

\begin{tabular}{|c|c|c|c|c|}
\hline \multirow{2}{*}{$№$} & The dispersions of adequacy & \multicolumn{2}{c|}{ The mean square errors } \\
\cline { 2 - 5 } & conditional designation & value & conditional designation & value \\
\hline 1 & $S_{u 1}^{2}$ & 0.13 & $\sigma^{2}\{y\}_{1}$ & 0.26 \\
\hline 2 & $S_{u 2}^{2}$ & 0.21 & $\sigma^{2}\{y\}_{2}$ & 0.42 \\
\hline 3 & $S_{u 3}^{2}$ & 0.13 & $\sigma^{2}\{y\}_{3}$ & 0.26 \\
\hline 4 & $S_{u 4}^{2}$ & 0.07 & $\sigma^{2}\{y\}_{4}$ & 0.14 \\
\hline 5 & $S_{u 5}^{2}$ & 0.13 & $\sigma^{2}\{y\}_{5}$ & 0.26 \\
\hline 6 & $S_{u 6}^{2}$ & 0.13 & $\sigma^{2}\{y\}_{6}$ & 0.26 \\
\hline 7 & $S_{u 7}^{2}$ & 0.16 & $\sigma^{2}\{y\}_{7}$ & 0.32 \\
\hline 8 & $S_{u 8}^{2}$ & 0.07 & $\sigma^{2}\{y\}_{8}$ & 0.14 \\
\hline 9 & $S_{u 9}^{2}$ & 0.07 & $\sigma^{2}\{y\}_{9}$ & 0.14 \\
\hline
\end{tabular}

Moreover:

$$
\begin{gathered}
\sum_{i=1}^{N} S_{u i}^{2}=1.1 \\
\sigma^{2}\{y\}=S_{0}^{2}=0.122 .
\end{gathered}
$$

Calculated value of the Cochran test at the $5 \%$ significance level was determined by formula (8):

$$
G_{c}=\frac{0.21}{1.1}=0.191
$$

Testing the experiment results by the Cochran test [20] for a fixed probability $\alpha=0.05$ confirmed the experiments reproducibility. Dispersion characterizing dispersal of the experiments results in combination of few factor levels: $S_{u \max }^{2}=0.21$. Calculated value of Cochran test: $G_{\text {calc }}=0.191$.

Table value of Cochran test: $G_{t a b}=0.478$.

So, the requirement is fulfilled:

$$
G_{\text {calc }}=0.191 \leq G_{t a b}=0.478 .
$$

At the next stage, the coefficients significance of regression equation is determined, analyzing the results according to the experimental design (Table 10). 
The experimental results of study of fracture stresses during the flexion of CM

\begin{tabular}{|c|c|c|c|c|}
\hline \multirow{2}{*}{ № } & \multicolumn{2}{|c|}{ Fracture stresses during the flexion, $\sigma_{f l}, \mathrm{MPa}$} & \multirow{2}{*}{ Average value, $\sigma_{f l}, \mathrm{MPa}$} \\
\cline { 2 - 4 } & 1 & 2 & 3 & 48.4 \\
\hline 1 & 48.0 & 48.5 & 48.7 & 50.0 \\
\hline 2 & 49.6 & 50.5 & 49.9 & 51.0 \\
\hline 3 & 50.7 & 50.9 & 51.4 & 49.3 \\
\hline 4 & 49.5 & 49.4 & 49.0 & 48.8 \\
\hline 5 & 48.9 & 48.4 & 49.1 & 50.2 \\
\hline 6 & 50.5 & 50.3 & 49.8 & 51.2 \\
\hline 7 & 51.6 & 50.8 & 51.2 & 48.6 \\
\hline 8 & 48.8 & 48.7 & 48.3 & 54.4 \\
\hline 9 & 54.5 & 54.1 & 54.6 & \\
\hline
\end{tabular}

Subsequently, dispersion of regression coefficients is determined by formulas (9-10). The significance of regression coefficients is determined according to Student's criterion, which table value is $t_{T}=2.1$. Calculated values of Student's criterion are shown in Table 11.

Table 11

Dispersion of coefficients of regression $\left(S_{b}^{2}\right)$ and calculated values of Student's criterion $\left(t_{p}\right)$

\begin{tabular}{|c|c|c|c|c|}
\hline \multirow{2}{*}{$№$} & \multicolumn{2}{|c|}{ Dispersion of coefficients of regression } & \multicolumn{2}{c|}{ Calculated values of Student's criterion } \\
\cline { 2 - 5 } & conditional designation & value & conditional designation & value \\
\hline 1 & $S_{b_{0}}^{2}$ & 0.014 & $t_{0 p}$ & 430.81 \\
\hline 2 & $S_{b_{1}}^{2}$ & 0.020 & $t_{1 p}$ & 1.28 \\
\hline 3 & $S_{b_{2}}^{2}$ & 0.020 & $t_{2 p}$ & 4.55 \\
\hline 4 & $S_{b_{11}}^{2}$ & 0.061 & $t_{11 p}$ & 2.36 \\
\hline 5 & $S_{b_{22}}^{2}$ & 0.061 & $t_{22 p}$ & 0.88 \\
\hline 6 & $S_{b_{12}}^{2}$ & 0.031 & $t_{12 p}$ & 4.7 \\
\hline
\end{tabular}

Calculated values of Student's criterion $t_{0}, t_{2}, t_{11}, t_{12}$, are larger than $t_{T}$, so it was considered that $b_{0}, b_{2}, b_{11}, b_{12}$ coefficients of the regression equation are significant. Calculated values $t_{1}, t_{22}$ are lower than $t_{T}$, so it was considered that $b_{1}, b_{22}$ coefficients of the regression equation are insignificant. As a result of rejection of insignificant coefficients, the following regression equation was received:

$$
y=50.46-0.65 x_{2}-0.58 x_{1}^{2}+0.83 x_{1} x_{2} .
$$

The adequacy of the model was checked by Fisher's test.

Calculated value of adequacy dispersion: $S_{u}^{2} \max =0.21$ (Table 9).

The mean square error: $S_{y}^{2}=0.122$.

So: $F=1.718$.

$F_{\left(0,05 ; f_{W} ; f_{u}\right)}$ - table value of Fisher's test in $5 \%$ significance level $\left(F_{(t)}=2.93\right)$.

Calculated value of Fisher's test is smaller than table on, so requirement (11) is fulfilled. Consequently, the equation adequately shows the composition formula.

After transformations in accordance with formula (13), the following regression equation with the natural values of variables was received:

$$
\sigma_{f l}=59.69-9.28 q_{1}^{2}+1.66 q_{1} q_{2}-7.32 q_{1}-1.155 q_{2} .
$$

Geometric interpretation of response surface is shown on Fig. 4-6. 


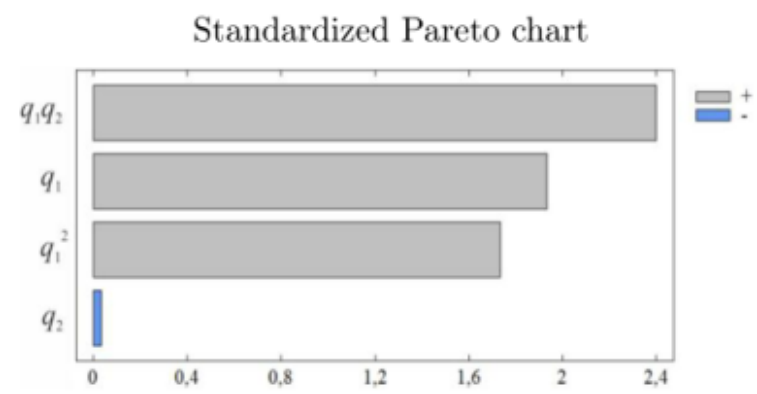

a)
Main effects $y$

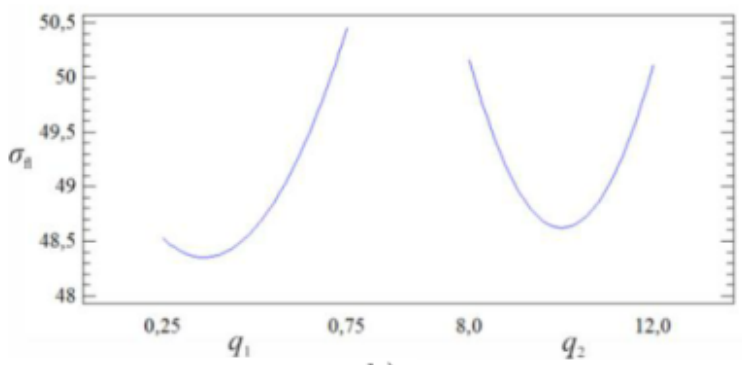

b)

Figure 4. Standardized Pareto chart (a) and main effects (b)

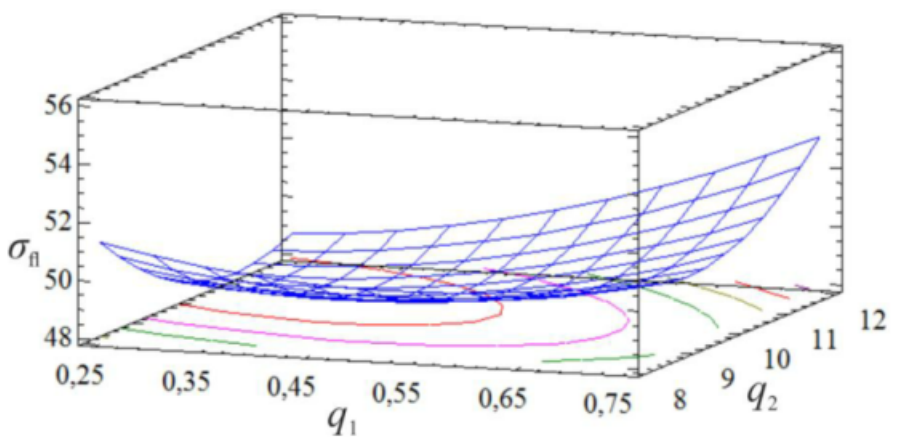

Figure 5. Estimated surface $\sigma_{f l}=f\left(q_{1}, q_{2}\right)$

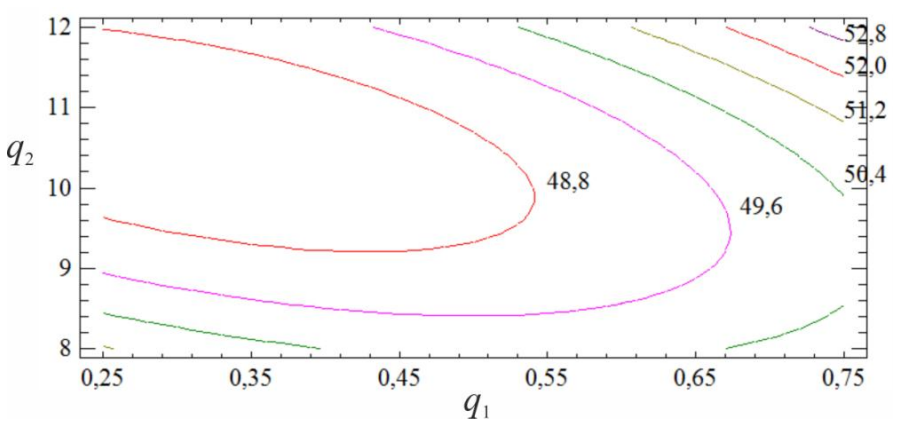

Figure 6. Contours of estimated response surface

The obtained results indicate that both factors of the regression equation are significant. It should be noted that the greatest influence on the output parameters of the composite have a pair interaction and linear and quadratic dependencies of the first factor. In the course of the analysis it was found that the indexes of fracture stresses during the flexion have the maximal values at the next content of components: the MBMA modifier is $0.25 \ldots 0.50$ pts. wt., PEPA hardener $-8 \ldots 10$ pts.wt. $\left(\sigma_{f l}=51.2 \ldots 54.4 \mathrm{MPa}\right)$. With further increase in the content of additives, a deterioration of the parameters of fracture stresses during the flexion was observed. In our opinion, this is a consequence of the oversaturation of the ingredients in the polymer matrix, which adversely affects the physical and mechanical properties of the material.

\section{Conclusions}

The critical content of the components: the MBMA modifier is $0.25 \ldots 0.50$ pts.wt., hardener PEPA $8 \ldots 10$ wt. per 100 pts.wt. of epoxy oligomer ED-20 was found by the method of mathematical planning of the experiment. The introduction of such ingredients into the epoxy binder increases the adhesion strength of matrix to $\sigma_{a}=28.9 \ldots 31.3 \mathrm{MPa}$ and the fracture stresses during the flexion to $\sigma_{f l}=51.2 \ldots 54.4 \mathrm{MPa}$. It is analyzed that with increasing the content of the modifier it is possible to increase the parameters of fracture 
stresses during the flexion. These studies will be presented in the next works. The obtained results allow to create materials with improved physical and mechanical properties in the complex. The obtained materials should be used in the form of protective coatings to improve the performance and repair of parts of transport equipment.

\section{References}

1 Xinyu Li. Mathematical modeling and evolutionary algorithm-based approach for integrated process planning and scheduling / Li Xinyu, Gao Liang, Shao Xinyu, Zhang Chaoyong, Wang Cuiyu // Computers \& Operations Research. - Vol. 37, Issue 4. - 2010. - P. 656-667.

2 Brailo M. The Investigation of Tribological Properties of Epoxy-Polyether Composite Materials for Using in the Friction Units of Means of Sea Transport / M. Brailo, A. Buketov, S. Yakushchenko, O. Sapronov, V. Vynar, O. Kobelnik // Materials Performance and Characterization. - 2018. - 7. - No. 1. - P. 275299.

3 Buketov A. Development of Epoxy-Polyester Composite with Improved Thermophysical Properties for Restoration of Details of Sea and River Transport / A. Buketov, M. Brailo, S. Yakushchenko, A. Sapronova // Advances in Materials Science and Engineering. - 2018. - Article ID 6378782. - 6 p.

4 Buketov A. The formulation of epoxy-polyester matrix with improved physical and mechanical properties for restoration of means of sea and river transport / A.V. Buketov, M.V. Brailo, S.V. Yakushchenko, O.O. Sapronov, S.O. Smetankin // Journal of Marine Engineering \& Technology. - 2018. - P. 1-6.

5 Buketov A.V. Dynamics of destruction of epoxy composites filled with ultra-dispersed diamond under impact conditions / A.V. Buketov, O.O. Sapronov, M.V. Brailo, P.O. Maruschak, S.V. Yakushchenko, S.V. Panin, V.D. Nigalatiy // Mechanics of Advanced Materials and Structures. - 2018. - P. 1-9.

6 Brailo M.V. Optimization of contents of two-component polydispersed filler by applying the mathematical design of experiment in forming composites for transport repairing / M.V. Brailo, A.V. Buketov, S.V. Yakushchenko, O.O. Sapronov, L. Dulebova // Bulletin of the Karaganda University. Mathematics series. - 2018. - №1 (89). - P. 93-104.

7 Sandler J. Development of a dispersion process for carbon nanotubes in an epoxy matrix and the resulting electrical properties / J. Sandler, M.S.P. Shaffer, T. Prasse, W. Bauhofer, K. Schulte, A.H. Windle // Polymer. - 1999. - 40. - № 21. - P. 5967-5971.

8 Akimov A.V. Development of polymer composites with improved thermophysical properties for shipbuilding and ship repair / A.V. Akimov, A.V. Buketov, O.O. Sapronov, M.V. Brailo, S.V. Yakushchenko, S.A. Smetankin // Composites: Mechanics, Computations, Applications: An International Journal. 2019. - 10. - No. 2. - P. 117-134.

9 Manwar Hussain. Mechanical property improvement of carbon fiber reinforced epoxy composites by $\mathrm{Al}_{2} \mathrm{O}_{3}$ filler dispersion / Hussain Manwar, Nakahira Atsushi, Niihara Koichi // Materials Letters. - 1996. - 26, No. 3. - P. 185-191.

10 Buketov A. Enhancing performance characteristics of equipment of sea and river transport by using epoxy composites / A. Buketov, P. Maruschak, O. Sapronov, D. Zinchenko, V. Yatsyuk, S. Panin // Transport. - 2016. - 31. - P. 333-342.

11 Buketov A.V. Optimization of components in development of polymeric coatings for restoration of transport vehicles / A.V. Buketov, M.V. Brailo, D.P. Stukhlyak, S.V. Yakushchenko, O.O. Sapronov, V.V. Cherniavskyi, V.M. Husiev, D.A. Dmitriev, V.M. Yatsyuk, O.M. Bezbakh, R.Yu. Negrutsa // Bulletin of the Karaganda University. Mathematics series. - 2018. - No. 4(92). - P. 119-131.

12 Buketov A. Investigation of thermophysical properties of epoxy nanocomposites / A. Buketov, P. Maruschak, O. Sapronov, M. Brailo, O. Leshchenko, L. Bencheikh, A. Menou // Molecular Crystals and Liquid Crystals. - 2016. - 628:1. - P. 167-179.

13 Fang F. Hierarchical Orthogonal Matrix Generation and Matrix-Vector Multiplications in Rigid Body Simulations / F. Fang, J. Huang, G. Huber, J.A. McCammon, B. Zhang // SIAM Journal on Scientific Computing. - 2018. - 40. - P. A1345-A1361.

14 Бондарь А.Г. Планирование эксперимента в химической технологии (основное положение, примеры и задачи): учеб. для студ. высш. учеб. завед. / А.Г. Бондарь, Г.А. Статюха. - Киев: Вищ. шк., 1976. $-184 \mathrm{c}$. 
15 Durán A.J. Orthogonal matrix polynomials satisfying second-order differential equations / A.J. Durán, F.A. Grünbaum // International Mathematics Research Notices. - 2004. - 2004. - P. 461-484.

16 Грушко И.М. Основы научных исследований: учеб. для техн. вузов / И.М. Грушко, В.В. Попов и др.; под ред. В.И. Крутова, В.В. Попова. - М.: Высш. шк., 1989. - 400 с.

17 Математические методы планирования эксперимента / под ред. В.В. Пененко. - Новосибирск: Наукa, 1981. - $250 \mathrm{c}$.

18 Kim T.K. $T$ test as a parametric statistic / T.K. Kim // Korean journal of anesthesiology. -2015 . -68. - P. 540 .

19 Chen Z. Is the weighted $z$ test the best method for combining probabilities from independent tests? / Z. Chen // Journal of evolutionary biology. - 2011. - 24. - P. 926-930.

20 Wilrich P.T. Critical values of Mandel's $h$ and $k$, the Grubbs and the Cochran test statistic / P.T. Wilrich // AStA Advances in Statistical Analysis. - 2013. - 97. - P. 1-10.

\author{
Н.В. Браило, О.М. Безбах, В.Н. Гусев, С.В. Якущенко
}

\title{
Көлік құралдарын қорғау үшін жақсартылған қасиеттері бар модификацияланған эпоксидті матрица
}

\begin{abstract}
Көлік құралдары бөлшектерінің пайдалану сипаттамаларын, оның ішінде олардың коррозияға қарсы қасиеттері мен тозуға төзімділігін арттыру үшін қорғаныштық полимерлік композиттік жабындарды пайдалану орынды екендігі негізделген. Физикалық-механикалық және жылу-физикалық қасиеттерінің көрсеткіштерін арттыру үшін эпоксидті байланыстырушы қоспаларды енгізу қажет: модификаторлар, пластификаторлар, дисперсиялық және талшықты толтырғыштар. Модификаторларды эпоксидті байланыстырғыш етіп енгізу өзекті болып табылады және де оларды кешенде пайдалану тиімді. Модификатор мен қатайтқыштың адгезиялық беріктікке және әзірленген эпоксидті композитті майыстыру кезінде кернеуді бұзатын әсері талданды. Экспериментті математикалық жоспарлау әдісімен компоненттердің сыни құрамы анықталды: модификатор МБМА 0,25 .. 0,50 масс. сағ, ПЕПА қатайтқыш - 8..10 масс. с 100 мас. сағ эпоксидті олигомер ЭД-20. Мұндай ингредиенттерді эпоксидті байланыстырғыш енгізу матрицаның адгезиялық беріктігінің көрсеткіштерін $\sigma_{a}=28.9 \ldots 31,3$ МПа дейін арттыруға мүмкіндік береді және бүгу кезінде қиратушы кернеулер $\sigma_{f l}=51,2 \ldots 54,4$ МПа дейін. Алынған нәтижелер кешенде физика-механикалық қасиеттерінің жақсартылған көрсеткіштері бар материалдарды жасауға мүмкіндік берді.
\end{abstract}

Kiлm сөздер: композит, эпоксидті матрица, экспериментті математикалық жоспарлау әдісі, регрессия теңдеуі.

\author{
Н.В. Браило, О.М. Безбах, В.Н. Гусев, С.В. Якущенко
}

\section{Модифицированная эпоксидная матрица с улучшенными свойствами для защиты транспортных средств}

\footnotetext{
Обосновано, что для повышения эксплуатационных характеристик деталей транспортных средств, в том числе их антикоррозийных свойств и износостойкости, целесообразно использовать защитные полимерные композитные покрытия. Показано, что для повышения показателей физико-механических и теплофизических свойств в эпоксидное связующее необходимо вводить добавки: модификаторы, пластификаторы, дисперсные и волокнистые наполнители. Актуальным является введение модификаторов в эпоксидное связующее, причем эффективно использовать их в комплексе. Проанализировано влияние модификатора и отвердителя на адгезионную прочность и разрушающие напряжения при изгибе разработанного эпоксидного композита. Методом математического планирования эксперимента установлено критическое содержание компонентов: модификатор МБМА - 0,25 . . 0,50 масс.ч, отвердитель ПЕПА - 8. . 10 масс.с на 100 масс.ч эпоксидного олигомера ЭД-20. Введение в эпоксидное связующее таких ингредиентов позволяет повысить показатели адгезионной прочности матрицы
} 
до $\sigma_{a}=28.9 \ldots 31,3$ МПа и разрушающих напряжений при сгибании до $\sigma_{f l}=51,2 \ldots 54,4$ МПа. Полученные результаты позволяют создать материалы с улучшенными в комплексе показателями физико-механических свойств.

Ключевые слова: композит, эпоксидная матрица, метод математического планирования эксперимента, уравнение регрессии.

\section{References}

1 Li, X., Gao, L., Shao, X., Zhang, C., \& Wang, C. (2010). Mathematical modeling and evolutionary algorithm-based approach for integrated process planning and scheduling. Computers \& Operations Research, 37(4), 656-667.

2 Brailo, M., Buketov, A., Yakushchenko, S., Sapronov, O., Vynar, V., \& Kobelnik, O. (2018). The investigation of tribological properties of epoxy-polyether composite materials for using in the friction units of means of Sea transport. Materials Performance and Characterization, 7(1), 275-299.

3 Buketov, A., Brailo, M., Yakushchenko, S., \& Sapronova, A. (2018). Development of Epoxy-Polyester Composite with Improved Thermophysical Properties for Restoration of Details of Sea and River Transport. Advances in Materials Science and Engineering, 6.

4 Buketov, A.V., Brailo, M.V., Yakushchenko, S.V., Sapronov, O.O., \& Smetankin, S.O. (2018). The formulation of epoxy-polyester matrix with improved physical and mechanical properties for restoration of means of sea and river transport. Journal of Marine Engineering 8 Technology, 1-6.

5 Buketov, A.V., Sapronov, O.O., Brailo, M.V., Maruschak, P.O., Yakushchenko, S.V., Panin, S.V., \& Nigalatiy, V.D. (2018). Dynamics of destruction of epoxy composites filled with ultra-dispersed diamond under impact conditions. Mechanics of Advanced Materials and Structures, 1-9.

6 Brailo, M.V., Buketov, A.V., Yakushchenko, S.V., Sapronov, O.O., \& Dulebova, L. (2018). Optimization of contents of two-component polydispersed filler by applying the mathematical design of experiment in forming composites for transport repairing. Bulletin of the Karaganda University. Mathematics series, 1(89), 93-104.

7 Sandler, J., Shaffer, M.S.P., Prasse, T., Bauhofer, W., Schulte, K., \& Windle, A.H. (1999). Development of a dispersion process for carbon nanotubes in an epoxy matrix and the resulting electrical properties. Polymer, 40(21), 5967-5971.

8 Akimov, A.V., Buketov, A.V., Sapronov, O.O., Brailo, M.V., Yakushchenko, S.V., \& Smetankin, S.A. (2019). Development of polymer composites with improved thermophysical properties for shipbuilding and ship repair. Composites: Mechanics, Computations, Applications: An International Journal, 10(2), $117-134$.

9 Hussain, M., Nakahira, A., \& Niihara, K. (1996). Mechanical property improvement of carbon fiber reinforced epoxy composites by $\mathrm{Al}_{2} \mathrm{O}_{3}$ filler dispersion. Materials Letters, 26(3), 185-191.

10 Buketov, A., Maruschak, P., Sapronov, O., Zinchenko, D., Yatsyuk, V., \& Panin, S. (2016). Enhancing performance characteristics of equipment of sea and river transport by using epoxy composites. Transport, 31(3), 333-342.

11 Buketov, A.V., Brailo, M.V., Stukhlyak, D.P., Yakushchenko, S.V., Sapronov, O.O., Cherniavskyi, V.V., Husiev, V.M., Dmitriev, D.A., Yatsyuk, V.M., Bezbakh, O.M., \& Negrutsa, R.Yu. (2018). Optimization of components in development of polymeric coatings for restoration of transport vehicles. Bulletin of the Karaganda University. Mathematics series, 4(92), 119-131.

12 Buketov, A., Maruschak, P., Sapronov, O., Brailo, M., Leshchenko, O., Bencheikh, L., \& Menou, A. (2016). Investigation of thermophysical properties of epoxy nanocomposites. Molecular Crystals and Liquid Crystals, 628(1), 167-179.

13 Fang, F., Huang, J., Huber, G., McCammon, J.A., \& Zhang, B. (2018). Hierarchical Orthogonal Matrix Generation and Matrix-Vector Multiplications in Rigid Body Simulations. SIAM Journal on Scientific Computing, 40(3), A1345-A1361.

14 Bondar, A.G., \& Statiukha, G.A. (1976). Planirovanie eksperimenta v khimicheskoi tekhnolohii [Planning an experiment in chemical technology]. Kiev: Vishcha shkola [in Russian]. 
15 Durán, A.J., \& Grünbaum, F.A. (2004). Orthogonal matrix polynomials satisfying second-order differential equations. International Mathematics Research Notices, 2004(10), 461-484.

16 Grushko, I.M., \& Popov, V.V. (1989). Osnovy nauchnykh issledovanii: uchebnik dlia tekhnicheskikh vuzov [Fundamentals of research: a textbook for technical universities]. V.I. Krutikov (Eds.). Moscow: Vysshaia shkola [in Russian].

17 Penenko, V.V. (Eds.). (1981). Matematicheskie metody planirovaniia eksperimenta [Mathematical methods of experimental design]. Novosibirsk: Nauka [in Russian].

18 Kim, T.K. (2015). T test as a parametric statistic. Korean journal of anesthesiology, 68(6), 540.

19 Chen, Z. (2011). Is the weighted $z$ test the best method for combining probabilities from independent tests? Journal of evolutionary biology, 24(4), 926-930.

20 Wilrich, P.T. (2013). Critical values of Mandel's $h$ and $k$, the Grubbs and the Cochran test statistic. AStA Advances in Statistical Analysis, 97(1), 1-10. 